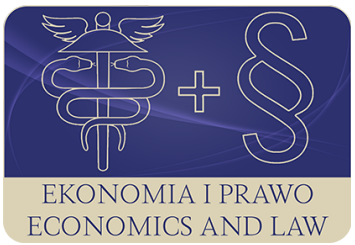

EKONOMIA I PRAWO. ECONOMICS AND LAW

Volume 19, Issue 3, September 2020

p-ISSN 1898-2255, e-ISSN 2392-1625

www.economicsandlaw.pl

EKONOMIA I PRAWO
ECONOMICS AND LAW

ORIGINAL ARTICLE

received 13.07.2019; revised 06.02.2020; accepted 30.09.2020

Citation: Janowski, M. (2020). Basic social economy entities and social and economic benefits resulting from their activity. Ekonomia i Prawo. Economics and Law, 19(3): 493-503.

doi:10.12775/EiP.2020.033.

\title{
Basic social economy entities and social and economic benefits resulting from their activity
}

\author{
MARCIN JANOWSKI \\ University of Szczecin, Institute of Spatial Management and Socio-Economic Geography, \\ ul. Cukrowa 8, 71-004 Szczecin, Poland \\ $\square$ marcin.janowski@wzieu.pl \\ (D) orcid.org/0000-0002-1819-5489
}

\begin{abstract}
Motivation: Social economy has been playing increasingly important role in the EU member states regional development overcoming the phenomena included in the widely understood social and economic exclusion and degradation of natural environment. It so happens because social entrepreneurship bridges the gap resulting from ineffective and imposed actions of the third participant of economic process, namely the government trying to overcome the effects of above mentioned negative phenomena. The social entrepreneurship is becoming more and more important because of the local and regional character of activities, addressed directly to endangered social groups and geographic areas, solving problems at their source. In the European Union nearly 11 million people are employed in the sector of social economy and the number has been growing for many years. Therefore, it seems important to make the topic of social entrepreneurship and its impact on regional development the subject of scientific studies. In recent years, more attention is paid to various concepts, fulfilling not only economic, but also social and environmental goals; one of them undoubtedly includes social economy.

Aim: This article aims at analysing specific form of entrepreneurship, namely social economy enterprises (PES), and presenting benefits resulting from their activity for regional development. The research methods applied in this study include inter alia the critical analysis of literature as well as evaluation and comparison of secondary research results from various sources. The scope of research refers to selected regions in Poland. The character of research work is illustrative.
\end{abstract}


Results: The article indicates how the concept of social economy helps to eliminate the negative effects of social and economic exclusion. Through actions at the regional lev$\mathrm{el}$, it is the social economy that acquires particular importance in voluntary, bottom-up solving of local community problems and supporting governmental activities. The results of the research of source materials presented in the article indicate that the level of development of social economy in different regions of Poland is of a varied nature, which may mean that its potential is not yet noticed everywhere.

Keywords: social economy; social objectives; economic objectives; regional development; spatial order

JEL: Rll; R23

\section{Introduction}

The economic development in Poland has been facing numerous barriers and problems the government is struggling with. Many of these problems result from the specificity of regions; therefore, it is so difficult to develop universal and system-based solutions on the central level. After political transformation, Poland had to adapt to the changing economic circumstances, and as a result many people lost their source of income as a consequence of shutting down unprofitable enterprises. The effects of such situation are particularly visible in agricultural and poorly urbanized regions where many people experienced social and economic marginalisation. Active governmental policy has been providing actions within social and professional integration of the socially excluded. One of the efficient instruments includes the concept of social economy where entities are established and operate in the excluded regions. The advantage of social economy entities over other instruments applied to combat social exclusion results from the fact that these entities operate exactly where they problems occur, adjusting the activities to the specificity and character of the region.

\section{Characteristics of social economy}

Social economy is identified with social entrepreneurship and is called the economy of solidarity. The term has got numerous definitions, which confirms the popularity of this economic concept. The diversity of concepts depends on various perspectives selected to analyse social economy. Some scientists focus on the achieved objectives, some focus on innovation, some on social group the support is addressed to within the concept of social economy.

Taking into account the objective of activities, the term, social economy, is applied to the sector of economy where organizations focus on social usefulness, and the surplus generated by these organizations are used to implement social objectives (Janowski, 2016, p. 68). The above mentioned definition underlines the importance of social objective which is superior to economic objective. Information on the hierarchy of social entrepreneurship objectives is important since there are other economic concepts fulfilling similar objectives but based 
on different scale of priorities. The author refers e.g. to the concept of socially responsible enterprise, which, also fulfils social objectives provided that economic objective is superior to social objective.

The definition emphasizing the innovative character of social economy defines the social entrepreneur as the one providing new possibilities, implementing innovative solutions, combining vision with pragmatism, solving problems in a creative and ethical manner, fully engaged in the area of social changes (Borstein, 2004, p. 39). The concept of innovative approach is often analysed together with the concept of social economy since it is considered one the most important features of social entrepreneur.

The definition emphasizing the target group, the addressee of actions within social economy, focuses its activity on undeserved people and people who experienced harm, and should aim at developing benefits resulting from social changes in favour of individuals and/or social groups (Martin \& Osberg, 2007, p. 29). These groups include the unemployed, people addicted to psychoactive substances, the disabled, people leaving correctional institutions, people from single-parent households, discriminated for origin or gender.

The above presented definitions indicate that for many researchers social economy has a different meaning resulting from their focus on selected area of activity related to this concept. Therefore, attempts to define social economy in a universal manner should include all aspects and definitions of this phenomenon. According to the National program for social economy development until 2023: social solidarity economy the definition combining the above mentioned aspects is the definition of social economy as the area of "civil and social activity, supporting, through public benefit economic activity: professional and social integration of people threatened with social marginalisation, job creation and provision of social public services (for the common interest) and regional development' (Ministry of Family, Labour and Social Policy, 2019b, p. 10). It is worth indicating that the above mentioned definition includes widely understood economic development as one of its main goals.

Social economy exists at the junction of many different elements, some of which can be defined as crucial. They include e.g. social competence, entrepreneurship, social mission or innovative approach. Each area affects and entwines with the other, shaping social economy. Characteristics of key areas of social economy is presented in scheme 1 .

In social economy there are numerous forms of such activity, and the most model division is the one differentiating:

- non-governmental organizations and entities defined by the Act on public benefit activities and volunteering (2003, art. $3 \$ 3$ ), called non-government organization (NGO);

- cooperatives;

- professional activation and social integration entities;

- country housewives' associations.

The complete division into social economy entities is presented in scheme 2. 


\section{Importance of social economy for social policy on the central and regional level}

It is estimated that in Europe nearly 160 million people are members of various social economy entities, engaged in 2 million social enterprises of various legal and organizational structure. Over 11 million people are employed in the sector of social economy, which constitutes $6 \%$ of all the employed in the European Union (European Commission, 2019). Nowadays, in Poland there are ca. 94 thou. social economy entities employing 354 thou. people, which constitutes ca. $2.3 \%$ of the employed in the entire economy in Poland (Ministry of Family, Labour and Social Policy, 2019b, p. 12). The data taking into account the number of entities and people employed divided by particular forms of activity of social economy entities is presented in table 1.

It should be noted that nearly $60 \%$ of social economy entities (PES) operate on a local and regional scale responding to current social issues in a given place, which confirms significant impact of social economy on regional development. The scale of activities of social economy organizations in the social and geographic area reads as follows (Stowarzyszenie Klon/Jawor, 2019, p. 10):

- $31 \%$ gminas and poviats;

- $31 \%$ whole country;

- $25 \%$ voivodships and regions;

- $9 \%$ other countries;

- $4 \%$ closest vicinity.

The studies conducted in 2018 by Stowarzyszenie Klon/Jawor aimed at defining social economy target groups also indicated that one of the largest groups of recipients regarding activities of social economy entities were local and regional communities $-62 \%$ recipients.

The social economy entities fulfil in the regions different functions most often related to the regional strategy and government policy for Responsible Growth. The most general division of objectives was presented in the previously mentioned National program for social economy development until 2023: social solidarity economy underlying the role of social economy in sustainable economic growth based on knowledge and organizational improvement within small and medium sized enterprises, and in socially sensitive and territorially sustainable development within the areas of social cohesion, active family support policy, improvement in service availability, in particular social and health services, support of groups threatened with exclusion and assurance of cohesion in actions for social integration. The strategy on national level is supported and coordinated on regional level. Such actions are sanctioned by law (Act on social assistance (2004) as one of the tasks of provincial local government). The act specifies detailed objectives including (Ministry of Family, Labour and Social Policy, 2018b, p. 45): 
- development of activation service infrastructure, integration and social and professional re-integration for people and families threatened with social exclusion;

- inspiration and promotion of new methods of activities in the area of activation, integration as well as social and professional re-integration;

- support for the development of partnership cooperation between local governments and entities providing activation, integration as well as social and professional re-integration services;

- monitoring the development of local social entrepreneurship enhancing social and professional activity;

- increased competence of services managing activation, integration and re-integration.

Studies prove that the most frequently selected areas of activity of social economy entities include sport and tourism managed by $35 \%$ of organizations, culture and art (14\%), education (13\%), health protection (8\%), social services (7\%) and local development (6\%) (Stowarzyszenie Klon/Jawor, 2019, p. 10). Data related to the area of activity and number of social economy entities is presented in table 2 .

In the light of above studies it should be noted that social economy focuses its activities within the so-called area of social and professional re-integration. In this area the leading social economy entities include Social Integration Centres (CIS), Social Integration Clubs (KIS), Professional Activation Centres (ZAZ) and Occupational Therapy Workshops (WTZ) which provided assistance to more than 43 thou. of people threatened with social exclusion in 2017. The social economy support provided to groups of people undeserved on the labour market is growing and in 2017 compared to 2016 the support increased by $4.9 \%$ (GUS, 2018, p. 1). The trend is visible in the long-term perspective, and studies indicate that within 5 years, increase has been observed in each of the defined forms of re-integration activity, which is presented in chart 1.

When presenting the level of involvement of social economy in the regional development, the scale of support for the inhabitants in particular regions should also be presented, indicating each of the forms of social and professional re-integration entities.

In 2017, in Poland there were 166 CIS centres which provided support for ca. 11.5 thou. people (increase on the previous year by $11.4 \%$ ). On average, there were 69 people who received support per one CIS. The largest number of CIS centres was situated in the following voivodships: Opole Province - 24, Pomerania - 21, Lubusz Province - 20 (GUS, 2018, p. 1). The CIS centres exerted the largest impact on people with long-term history of unemployment. This support group constituted $49 \%$ of the reported. The disabled, living in particular regions constituted $11.7 \%$ of the reported. People addicted to alcohol constituted $11.2 \%$ of all reported. Other undeserved groups constituted in total $2.1 \%$, and they experienced various addictions to narcotic drugs, mental diseases and problems affecting refugees. 
The social economy entities, operating within the WTZ constitute the largest group supporting regional communities, which is proved by statistics; in 2017, there were 715 of such organizations in Poland. The WTZ support was provided for 27.1 thou. of the disabled. The average for the whole country totals 38 people per one WTZ. Compared to the previous year, there was an increase in provided support by 0.6 thou. people. The regions where WTZ entities were most active include: Greater Poland - 87 entities, Masovia - 83 and Lesser Poland - 67 (GUS, 2018, p. 1). The development of Occupational Therapy Workshops in particular regions in Poland is important taking into account local impact on the activation of the disabled who are less mobile than other people and therefore, it is more difficult for them to be begin any activity related to moving e.g. to other regions or support centres for people with disabilities.

In 2017, in Poland there were 109 ZAZ; they also increased in number compared to the previous year and 6 more centres were established. ZAZ centres employed ca. 6 thou. people. This group of entities is most frequent in Subcarpathia and Silesia regions - there were $13 \mathrm{ZAZ}$ centres in each region. The third region was Lesser Poland, with 10 such forms of social economy entities (GUS, 2018, p. 1). The Professional Activation Centres, just as WTZ entities, offer their support mainly to the disabled and people with moderate disabilities. Among the employed, this undeserved group constituted 4453 people, including 2707 people with significant disabilities, 1716 people with moderate disabilities and 28 people with minor disabilities (Urząd Marszałkowski Województwa Zachodniopomorskiego, 2017, p. 21).

KIS operate most frequently at territorial local governments, and there were 219 of them in 2017. They provide various services for the integration of local communities. They are social economy entities operating at social welfare centres or social welfare homes, and they constitute $66 \%$ of all KIS clubs, the other are managed by non-profit organizations. The largest number of KIS clubs was recorded in the following voivodships: Warmia-Masuria - 36, Silesia - 35 and Lesser Poland - 30 (GUS, 2018, p. 1). Social Integration Clubs represent the smallest growth in number among all social economy entities; only two more KIS clubs were established. The consolidated data on the activity of social economy entities regarding professional activation is presented in chart 2.

The above analysis proves that social economy entities play an important role in the regional communities in Poland, and are invaluable instruments in solving social problems in local and regional areas. Their effectiveness results from the fact that they are established locally, react to social issues within their area of activity, offering support to people in local communities, and are developed in places where the excluded groups reside. It particularly refers to activities related to professional activation which, in turn, has significant impact on regional development in Poland. 


\section{Conclusion}

The impact of social economy on development, in particular with regard to social and economic aspect can be defined as significant and is gaining popularity. The grassroots activities of initiative groups reacting to current issues existing in various regions in Poland become instruments supporting the national policy, which is proven by development programmes with social economy as an important component. The results of activities of social economy entities, presented in this article, in particular in combating unemployment among the disabled, the excluded, people with long-term history of unemployment or the addicted prove that such activities become important elements in the regional policy of all voivodships. Nowadays, social economy is perceived as a bridge between free market economic activities and state interventionism, reducing deficiencies of both areas. It is estimated that social economy will play increasing more important role in activities supporting the economic development in Poland in the coming years, similar to the situation in Western Europe. It is reflected in the government's expectations indicating social economy as an important instrument in the implementation of public policy objectives regarding employment and reintegration, social services and local development. Experts indicate that the labour shortages in Poland until 2040 are estimated at 4.5 million people (Ministry of Family, Labour and Social Policy, 2019a, p. 8). In the light of such forecast, social economy will focus on supporting the government's policy objectives, such as activation of people previously inactive professionally on the labour market, activation of the unemployed who are the furthest from the labour market and who nowadays represent over 818,000 people (Ministry of Family, Labour and Social Policy, 2018a), and support for actions related to managing the migration policy providing favourable labour conditions for foreigners.

\section{References}

Borstein, D. (2004). How to change the world: social entrepreneurs and the power of new ideas. New York: Oxford University Press.

European Commission. (2019). Social economy in the EU. Retrieved 21.05.2019 from http://ec.europa.eu.

GUS. (2018). Social integration centers, social integration clubs, vocational activity establishments and occupational therapy workshops in 2017. Retrieved 24.05.2019 from https://stat.gov.pl.

Janowski, M. (2016). Cele społeczne i ekonomiczne realizowane w podmiotach biznesowych i ekonomii społecznej. In H. Babis (Ed.), Przedsiębiorczość spoteczna jako forma aktywności ekonomicznej i spotecznej w województwie zachodniopomorskim. Szczecin: Print Group.

Janowski, M. (2019). Istota przedsiębiorczości społecznej. In K. Słupińska, \& M. Janowski (Eds.), Nauki ekonomiczne wobec zmian rynkowych z punktu widzenia mtodych naukowców. Szczecin: Uniwersytet Szczeciński. 
Martin, R.L., \& Osberg, S. (2007), Social entrepreneurship: the case for definition. Stanford Social Innovation Review, spring.

Ministry of Family, Labour and Social Policy. (2018a). Bezrobocie rejestrowane. Retrieved 24.05.2019 from https://psz.praca.gov.pl.

Ministry of Family, Labour and Social Policy. (2018b). Sprawozdanie z realizacji Krajowego Programu Rozwoju Ekonomii Spotecznej (KPRES) za rok 2016. Retreived 15.11.2019 from https://www.ekonomiaspoleczna.gov.pl.

Ministry of Family, Labour and Social Policy. (2019a). Ekonomia spoteczna w Polsce $w$ nowej perspektywie finansowej 2020+: wnioski i rekomendowane rozwiązania. Retrieved 15.11.2019 from https://www.ekonomiaspoleczna.gov. pl.

Ministry of Family, Labour and Social Policy. (2019b). Krajowy program rozwoju ekonomii spotecznej do 2023 roku: ekonomia solidarności spotecznej. Retrieved 24.05.2019 from https://www.ekonomiaspoleczna.gov.pl.

Stowarzyszenie Klon/Jawor. (2019). Kondycja organizacji pozarządowych 2018. Retrieved 24.05.2019 from https://api.ngo.pl.

Urząd Marszałkowski Województwa Zachodniopomorskiego. (2017). Zachodniopomorski program rozwoju ekonomii spotecznej na lata 2018-2022. Retrieved 15.11.2019 from http://eregion.wzp.pl.

Ustawa z dnia 12 marca 2004 r. o pomocy społecznej [Act of 12 March 2004 on social assistance] (Dz.U. $2004 \mathrm{nr} 64$ poz. 593) (Poland).

Ustawa z dnia 24 kwietnia 2003 r. o działalności pożytku publicznego i o wolontariacie [Act of 24 April 2003 on public benefit activities and volunteering] (Dz.U. 2003 nr 96 poz. 873) (Poland).

\section{Acknowledgements}

Author contributions: author has given an approval to the final version of the article.

Funding: this research was funded by the University of Szczecin, Faculty of Management and Economic of Services, Department of Economic statutory sources.

Note: the results of this study were presented at 8th International Scientific Conference: Contemporary Economic Problems 'Social-economic problems in the era of globalization: theory and practice' (May, 22, 2019, Torun, Poland). 


\section{Appendix}

Table 1.

Number of social economy entities and their employees in Poland in 2017 (in thousands)

\begin{tabular}{lcc}
\hline \multicolumn{1}{c}{ Type of entity } & Number of active entities & Number of employees \\
\hline associations & 23.4 & 85.4 \\
foundations & 13.6 & 28.3 \\
social religious entities & 1.9 & 40.4 \\
self-regulatory entities & 0.8 & 2.7 \\
agricultural associations & 1.2 & 0.2 \\
worker cooperatives & 0.5 & 16.0 \\
disabled cooperatives & 0.2 & 17.3 \\
social cooperatives & 0.9 & 4.2 \\
supported employment & 1 & 147.5 \\
enterprises & - & - \\
social integration centres & 0.2 & 1.2 \\
social integration clubs & 0.2 & - \\
professional activation centres & 0.1 & 1.5 \\
occupational therapy workshops & 0.7 & 9.9 \\
\hline total & 94.7 & 354.6 \\
\hline
\end{tabular}

Source: Own preparation based on Ministry of Family, Labour and Social Policy (2019b, p. 13).

Table 2.

Areas of human activity most frequently supported by social economy entities (in thousands)

\begin{tabular}{lc}
\hline \multicolumn{1}{c}{ Area of activity } & Number of social economy entities \\
\hline sport, tourism, recreation and hobby & 28 \\
culture and art & 1 \\
education and upbringing & 10 \\
health protection & 6 \\
social services, social assistance & 5 \\
local development & 4 \\
other & - \\
\hline
\end{tabular}

Source: Own preparation based on Stowarzyszenie Klon/Jawor (2019, p. 10). 


\section{Scheme 1 .}

\section{Areas of social economy}

\section{OBJECTIVES}

Social economy develops within social and economic objectives. In social economy the hierarchy of these objectives is important. Social objectives are superior. Economic objectives are inferior and are used to fulfil social objectives.

\begin{tabular}{|l|c|c|}
\hline $\begin{array}{c}\text { They naturally result from social } \\
\text { innovation and involve long-term } \\
\text { activities. Activities within social } \\
\text { entrepreneurship should always take } \\
\text { into account effects from a long-term } \\
\text { perspective. }\end{array}$ & $\begin{array}{c}\text { SOCIAL } \\
\text { ECONOMY }\end{array}$ & $\begin{array}{c}\text { Mocial mission is a crucial element in } \\
\text { social economy, related to solving } \\
\text { social problems, including e.g.: } \\
\text { poverty, unemployment, degradation } \\
\text { of natural environment. }\end{array}$ \\
\hline $\begin{array}{c}\text { ENTREPRENEURSHIP } \\
\begin{array}{c}\text { Social economy defined as perception of } \\
\text { opportunities and ability to use them as well as } \\
\text { taking risks. }\end{array}\end{array}$ & $\begin{array}{c}\text { INNOVATION } \\
\text { Defining new methods for solving long-term } \\
\text { problems may refer to social innovation, being } \\
\text { an indispensable part of social economy. }\end{array}$ \\
\hline
\end{tabular}

Source: Own preparation based on Janowski (2019, p. 14).

\section{Scheme 2.}

Types of social economy entities

\section{NGO \\ associations, foundations, social religious \\ entities, self-regulatory organizations, agricultural associations}

\section{COUNTRY HOUSEWIVES'} ASSOCIATIONS

all types of organizations without legal personality

\section{COOPERATIVES IN TOTAL}

work cooperatives, social cooperatives, the disabled cooperatives, worker cooperatives

PROFESSIONAL ACTIVATION ENTITIES

Centers for Social Integration, Social

Integration Clubs, Proffesional Activation

Centers, Occupational Therapy Workshops

Source: Own preparation. 


\section{Chart 1.}

Number of active social and professional re-integration entities between 2012 and 2017 in Poland

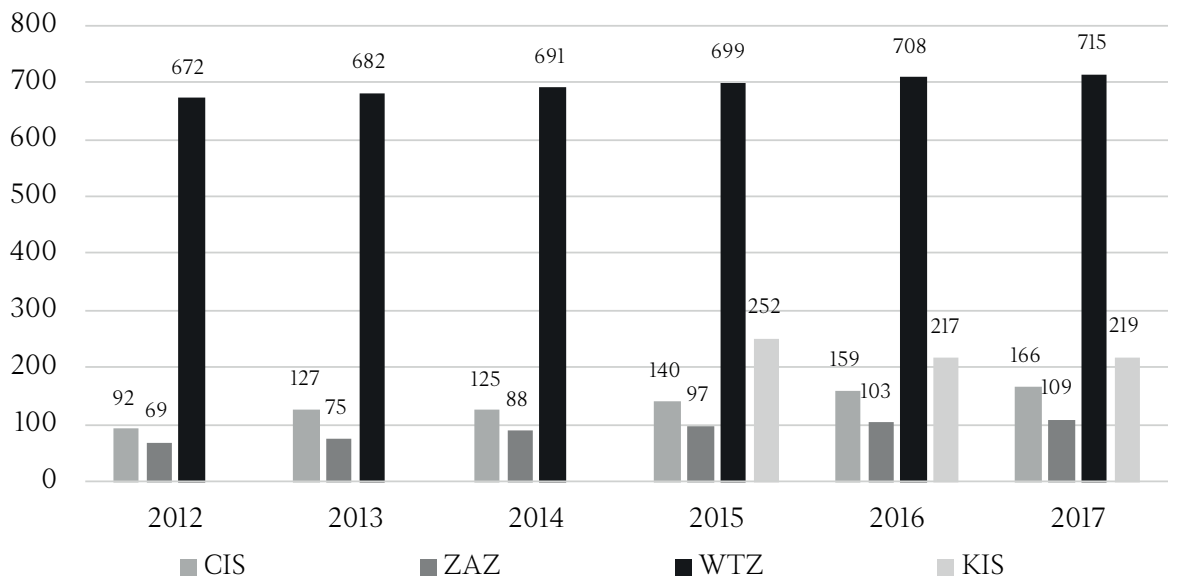

Source: Own preparation based on GUS (2018, pp. 2-6).

Chart 2.

KIS, WTZ, ZAZ and CIS per voivodships in Poland in 2017

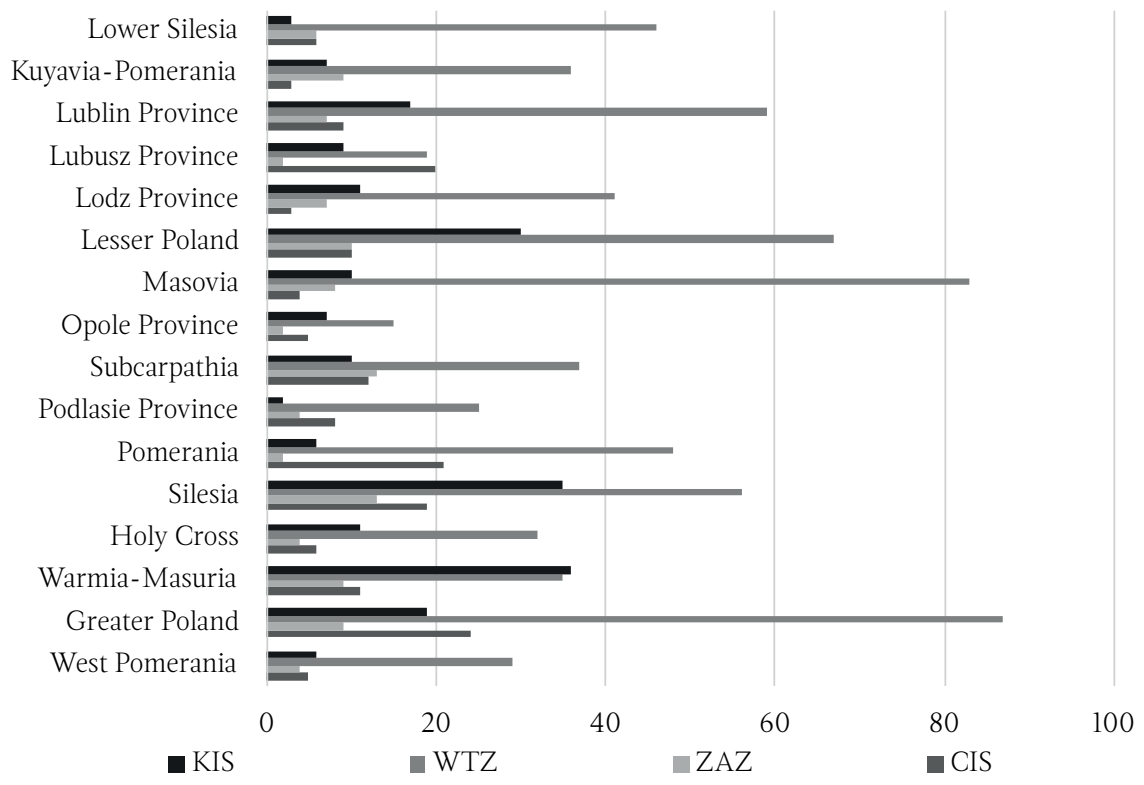

Source: Own preparation based on GUS (2018, pp. 2-6). 
